\title{
PENYUSUNAN INDEKS HUBUNGAN MANUSIA TAHUN 2018 BERDASARKAN KONSEP TRI HITA KARANA
}

\author{
(HUMAN RELATIONSHIP INDEX ARRANGEMENT IN 2018 BASED ON THE CONCEPT OF \\ TRI HITA KARANA)
}

\author{
Suciarti Pertiwi ${ }^{1}$, Hardius Usman ${ }^{2}$ \\ ${ }^{1}$ Badan Pusat Statistik \\ ${ }^{2}$ Dosen Politeknik Statistika STIS \\ Kampus Politeknik Statistika STIS, Jalan Otto Iskandardinata 64C Jakarta \\ E-mail: 16.9438@stis.ac.id
}

\begin{abstract}
ABSTRAK
Konsep sustainability as opportunity yang dikembangkan oleh Bank Dunia memandang bahwa pembangunan akan berkelanjutan jika dapat memberikan income tidak hanya pada modal ekonomi, tetapi juga modal manusia,sosial dan alam. Untuk mengukur modal sosial, dilakukan penyusunan Indeks Hubungan Manusia yang mengadaptasi konsep Tri Hita Karana (THK) dalam masyarakat agama hindu Provinsi Bali. THK mengajarkan bahwa keharmonisan dan kesejahteraan akan dicapai dengan selarasnya hubungan antara manusia dengan Tuhan, hubungan dengan manusia, dan hubungan dengan lingkungannya. Konsep THK ini memiliki kemungkinan untuk diterapkan pada seluruh provinsi Indonesia dengan keragaman kondisi sosial budaya, agama, kebudayaan dan lainnya.Indeks ini belum pernah disusun dalam skala nasional sebelumnya sehingga perlu dilakukan eksplorasi dalam menentukan indikator penyusunnya. Penggunaan Analisis Faktor dilakukan untuk mengekstraksi 82 indikator yang didapatkan dari SUSENAS MSBP 2018, Hansos 2017 dan SPTK 2017, dan dihasilkan 64 indikator penyusun IHM. IHM menunjukkan terdapat korelasi antara IHM dengan $\operatorname{IPM}(0,436)$ dan Inkesra $(0,554)$, provinsi dengan nilai IHM tertinggi adalah DIY, Jawa Tengah dan Bali.
\end{abstract}

Kata kunci: analisis faktor, indeks, kesejahteraan,THK

\section{ABSTRACT}

The concept of sustainability as opportunity developed by the World Bank views that development will be sustainable if it can provide income not only for economic capital, but also human, social and natural capital. To measure social capital, the Human Relations Index is compiled which adapts the Tri Hita Karana (THK) concept in the Hindu religious community of Bali Province. THK explained that harmony and prosperity will be achieved by being in harmony with the relationship between humans and God, the relationship with humans, and the relationship with the environment. The THK concept has the possibility to be applied to all provinces in Indonesia with a variety of socio-cultural, religious, cultural and other conditions. This index has never been arranged on a national scale before so it needs further exploration in determining its constituent indicators. The use of factor analysis was conducted to extract 82 indicators obtained from the SUSENAS MSBP 2018, Hansos 2017 and SPTK 2017, and produced 64 indicators of IHM. IHM shows that there is a correlation between IHM and IPM (0.436) and Inkesra (0.554), with the highest provincial value on the IHM is DIY, Central Java and Bali.

Keywords: factor analysis, index, welfare, THK

\section{PENDAHULUAN}

Pembukaan Undang-Undang Dasar 1945 pada alinea ke empat menyebutkan bahwa salah satu tujuan bangsa adalah memajukan kesejahteraan umum. Selama ini, kesejahteraan seringkali hanya dipandang dari aspek ekonomi padahal aspek tersebut tidak cukup untuk mengukur kesejahteraan masyarakat. Bank Dunia mengembangkan konsep yang dikenal dengan sustainability as opportunity. Menurut Iwan (1997), konsep ini memandang bahwa pembangunan akan berkelanjutan jika dapat memberikan income untuk generasi mendatang atau minimal sama dengan saat ini mengenai kemungkinan pertumbuhan capital yang berbentuk modal manusia (investasi dalam pendidikan, kesehatan, atau gizi), modal sosial (fungsi dan keberadaan kelembagaan dan budaya dalam masyarakat), modal alam (fungsi dan keberadaan sumberdaya 902 
alam dan lingkungan) dan modal ekonomi (investasi dalam anggaran perekonomian). Untuk melengkapi indikator pembangunan ekonomi, Indonesia memiliki indikator pembangunan sosial yaitu Indeks Pembangunan Manusia (IPM). Indeks tersebut dihitung dengan 3 dimensi dasar yang tergolong dalam modal manusia. Sedangkan sisi lain seperti sisi sosial, keterkaitan dengan lingkungan dan sisi spiritual belum dilibatkan dalam perhitungan. Padahal, peran modal sosial dan alam diperlukan untuk mendukung pembangunan manusia ditengah keberagaman budaya yang melekat dalam masyarakat Indonesia serta kekayaan alam melimpah yang terkandung didalamnya.

Indonesia memiliki kekayaan kebudayaan dan tersebar di seluruh penjuru Nusantara yang dapat menjadi kekuatan penggerak dan modal dasar pembangunan. Salah satu kearifan lokal yang dimiliki Indonesia dan termasuk kedalam Outstanding Universal Value (OUV) oleh UNESCO adalah sistem subak di Provinsi Bali. Sistem Subak sebagai bentuk manifestasi langsung dari filosofi Tri Hita Karana ini ditetapkan sebagai Warisan Budaya Dunia (World Cultural Heritage) UNESCO per tanggal 6 Juli 2012 (Komisi Nasional Indonesia untuk UNESCO, 2019). Oleh karena itu, bentuk filosofi didalamnya perlu dilindungi. Konsep Tri Hita Karana lebih jauh dijelaskan oleh Drs. I Ketut Wiana, M.Ag (2007) sebagai tiga aspek hubungan yang dimiliki oleh setiap manusia, yaitu (1) hubungan sosial bermasyarakat, (2) hubungan spiritual, dan (3) hubungan lingkungan, yang saling berkaitan untuk membentuk kesatuan sistem dalam menciptakan keselarasan, kesejahteraan dan kedamaian hidup. Konsep ini diteliti dalam Praktik Kerja Lapangan yang dilaksanakan oleh Politeknik Statistika STIS pada bulan Febuari 2019 lalu di daerah Denpasar, Badung, Gianyar dan Tabanan, menghasilkan angka indeks THK sebesar 73,91. Indeks tersebut dapat dikategorikan tinggi, yang berarti masyarakat Bali memiliki kepatuhan tinggi untuk menerapkan nilai-nilai, norma dan ajaran budaya dan agamanya. Hal ini tentu dapat dimengerti karena konsep ini dilandaskan pada budaya yang hidup dan berkembang disana. Dengan keragaman budaya serta kearifan lokal yang dimiliki di setiap provinsi di Indonesia, bagaimanakah jika konsep ini diterapkan dalam skala nasional?

Ketiga aspek dalam konsep Tri Hita Karana perlu lebih jauh dieksplorasi mengenai peranannya dalam kesejahteraan rakyat. Dalam menentukan strategi pembangunan berkelanjutan, Rahadian (2016) menyebutkan bahwa pembangunan memerlukan pendekatan integratif yang mengutamakan keterkaitan antara manusia dengan alam dimana manusia mempengaruhi alam dengan cara yang bermanfaat atau merusak. Iwan (1997) menganalisis keadaan modal sosial dalam pembangunan perkotaan di Indonesia berdasarkan data Susenas 1995 dan menunjukkan bahwa kemajuan pembangunan selama ini memang sejalan dengan meningkatnya kegiatan sosial budaya dan masih lekatnya nilai keagamaan khususnya pada penduduk pedesaan. Hal ini didukung oleh Sitepu (2006) yang menemukan bahwa organisasi sosial lokal berperan dalam pembangunan kesejahteraan sosial. Alfian (1982) dalam Irwan (2002) mengatakan fungsi kebudayaan dalam perubahan masyarakat harus ditegaskan kembali dan berfungsi dalam mengevaluasi setiap perubahan sehingga perubahan itu tidak berada di luar jalur nilai-nilai yang disepakati.

Ketiga aspek dalam konsep TKH diatas selayaknya mendasari proses pembangunan yang dilakukan selama ini. Tetapi, proses pembangunan belum mengimbangi aspek hubungan manusia dengan alam lingkungan. Sedangkan kedua aspek hubungan tersebut dilandari dari aspek utama yang mengikat yaitu aspek ketuhanan. Kegiatan pembangunan dilakukan oleh manusia terlepas dari dampaknya terhadap lingkungan akan menyebabkan kerusakan terhadap kualitas lingkungan dan akan mempengaruhi kesejahteraan dan keharmonisan penduduk setempat (Haryati dan Nurasyikin, 2011). Dalam kurun waktu 2014 hingga 2018, perekonomian Indonesia mampu tumbuh rata-rata dalam lima tahun sebesar $8,85 \%$ namun disertai dengan pengurangan luas tutupan hutan di Indonesia sekitar 1,40 \% atau sebesar 2.685.0128 hektar (BPS,2018). Selain itu, pembangunan secara materil tidak selalu menjadi faktor penentu utama dalam membangun kesejahteraan masyarakat. Pada tahun 2018, Provinsi Maluku menjadi provinsi dengan tingkat kebahagiaan tertinggi (BPS). Hal ini didukung oleh Munayati Salam (2018) yang menjabarkan bahwa kebahagiaan di daerah Maluku Utara tidak dicapai dari besarnya angka perekonomian, 
tetapi berdasarkan tingginya indikator interaksi diantara sesama masyarakat sehingga memunculkan keharmonisan dalam kehidupan sehari-hari. Pada aspek selanjutnya, pentingnya hubungan manusia dengan Tuhan sebagai landasan seseorang beragama dan bermasyarakat sebagai tuntunan untuk mencapai kesejahteraan hidup pun telah disinggung oleh Presiden Soeharto. Soeharto dalam Irwan (2002) mengatakan bahwa pemahaman kebendaan dan kuantitatif saja sudah tidak memadai lagi, belum tentu menghasilkan kesejahteraan dan kebahagiaan, bahkan ternyata dapat membawa dampak sosial budaya yang kurang menguntungkan.Pemikiran ini menjelaskan perlunya mengkaji ulang target dan cara yang dilakukan dalam proses pembangunan.

Untuk menjawab kondisi tersebut, diperlukan suatu indikator yang menghitung modal lain dalam kesejahteraan mansyarakat. Penelitian ini bertujuan untuk membangun suatu indikator untuk mengukur kesejahteraan masyarakat dengan mengadopsi konsep Tri Hita Karana. Konsep THK ini memiliki kemungkinan untuk diterapkan secara nasional dengan keragaman kondisi sosial budaya, agama, adat dan lainnya pada setiap provinsi sehingga menjadi sudut pandang baru untuk mengukur kesejahteraan masyarakat yang dinamakan Indeks Hubungan Manusia (IHM). IHM merupakan indeks komposit yang disusun atas tiga hubungan, yaitu hubungan manusia dengan Tuhan, manusia dan alam. Indeks ini belum pernah disusun dalam skala nasional sebelumnya sehingga perlu dilakukan eksplorasi dalam menentukan indikator penyusunnya. Setelah terbentuk IHM, penelitian ini mencoba menguji korelasinya dengan beberapa indikator lain yaitu IPM dan Inkesra untuk melihat apakah indeks ini dapat mencerminkan kondisi kesejahteraan masyarakat.

\section{METODE}

\section{METODE PENGUMPULAN DATA}

Penelitian ini mencakup 34 provinsi di Indonesia pada tahun 2018. Pembentukan indeks komposit pada penelitian ini tersusun atas 3 indeks tunggal yaitu Indeks Ketuhanan, Indeks Kemanusiaan dan Indeks Lingkungan Hidup. Penelitian ini menggunakan data sekunder yang didapat dari BPS dengan rincian sebagai berikut : SUSENAS Modul SBP 2018, SUSENAS Modul Hansos 2017 dan SPTK 2017. Data 2017 digunakan untuk melengkapi data 2018 dengan asumsi tidak terjadi perubahan yang signifikan. Selain itu, survei hanya dilaksanakan pada tahun tersebut dari periode tiga tahunan yang dilakukan. Hal ini menjadi kelemahan pada penelitian ini karena tidak bisa membentuk indeks tahunan.

\section{METODE PENGOLAHAN DATA}

Pembentukan indeks dalam pelitian ini menggunakan Analisis Faktor metode PCA dengan tujuan analisis yaitu Analisis Eksploratori. Analisis faktor adalah salah satu analisis multivariat yang digunakan untuk mereduksi atau meringkas variabel yang banyak menjadi variabel baru yang lebih sedikit yang disebut sebagai faktor dan masih memuat sebagian besar informasi dari variabel asli (Supranto, 2004).Terdapat statistik yang berhubungan dengan analisis faktor yaitu Bartlett's test of sphericity, untuk menguji ada/tidaknya korelasi antar variabel. Statistik lain yang berhubungan dengan analisis faktor yaitu KMO (Kaiser-Meyer-Olkin). KMO digunakan untuk menguji kelayakan data. Nilai KMO yang kecil mengindikasikan bahwa penggunaan Analisis Faktor harus dipertimbangkan kembali, karena korelasi antara peubah asal tidak dapat diterangkan oleh peubah lain. Kaiser dan Rice (1974) dalam Sharma (1996) menetapkan kriteria pengukuran bahwa nilai KMO sebesar 0,90 adalah sangat bagus; 0,80 adalah bagus; 0,70 adalah cukup; 0,60 adalah kurang; 0,50 adalah jelek, dan dibawah 0,50 tidak dapat diterima.

Proses pembentukan dilakukan masing- masing indeks tunggal (Indeks Ketuhanan, Indeks Kemanusiaan, Indeks Lingkungan Hidup) secara terpisah lalu selanjutnya diagregasi secara aritmatika untuk membentuk indeks komposit (IHM). Pembentukan Indeks Komposit menurut OECD (Joint Research Centre-European Commission, 2008), mengikuti langkah-langkah sebagai berikut :

1)Membangun kerangka teoritis, 
2)Pemilihan data,

3)Imputasi pada missing data,

4)Analisis multivariat,

5)Normalisasi,

6)Pembobotan dan agregasi,

7) Robustness dan sensitivitas,

8)Dekomposisi,

9) Hubungan dengan indikator lain,

10)Presentasi dan visualisasi.

Indikator dipilih berdasarkan ketersediaan dan kesesuaian data pada sumber data dan teori terkait. Selanjutnya dilakukan persiapan data dengan mengecek missing value dan me- recode data sekaligus menyamakan arah indikator. Selanjutnya data dinormalisasi dengan metode minmax. Langkah selanjutnya yaitu mereduksi indikator dengan cara analisis faktor. Supranto (2017) menjelaskan, dalam analisis faktor terdapat dua metode yang dapat digunakan, yaitu principal components analysis dan common factor analysis. Principal components analysis (PCA) bertujuan untuk menentukan banyaknya faktor minimum dengan memperhitungkan varian maksimum dalam data. Untuk mendukung tujuan penelitian, metode yang digunakan yaitu metode PCA.

Dalam melakukan analisis faktor, indikator diuji terlebih dahulu dengan Bartlett's test of sphericity dan dilihat KMO-nya. Apabila telah memenuhi syarat, selanjutnya yaitu penentuan indikator dari faktor yang terbentuk setelah dilakukan rotasi faktor metode varimax. Penentuan banyaknya faktor didasarkan pada nilai eigen value (diambil faktor dengan eigen value $>1$ ), presentase kumulatif varians (60-75\% untuk penelitian sosial). Untuk Indeks Ketuhanan dan Indeks Kemanusiaan, nilai kontribusi setiap indikator dilakukan secara unequal. Bobot setiap indikator dihitung berdasarkan nilai loading factors serta nilai rotation sums of squared loading (\% of variance) melalui 2 tahap :

c) penghitungan bobot tiap indikator dengan formula

$$
\text { Bobot }_{i}=\frac{\text { Loading factor }_{i}}{\text { Total loading }_{i}} \times \frac{\% \text { of } \text { variance }_{i}}{100}
$$

dimana

Total loading ${ }_{i}=\sum$ Loading factor $_{i}$

an kontribusi/bobot standar tiap indikator dalam satu dimensi dengan formula

$$
\text { Bobot Standar }_{i}=\frac{\text { Bobot }_{i}}{\sum \text { Bobot }_{i}} \text {. }
$$

Sedangkan untuk Indeks Lingkungan Hidup (ILH), ekstraksi dilakukan secara terpisah mengikuti kerangka pikir penelitian (reduksi indikator dilakukan pada masing-masing dimensi lalu selanjutnya hasil indeks dimensi diagregasi secara aritmatika membentuk ILH). Nilai kontribusi setiap indikator tersebut digunakan sebagai penimbang/pembobot masing-masing indikator. Selanjutnya, dilakukan agregasi tiga indeks secara equal.

\section{METODE ANALISIS}

Analisis deskriptif pada penelitian ini menyajikan bentuk grafik dan peta tematik untuk indeks komposit. Penyajian ini dilakukan untuk melihat sebaran nilai indeks dan pengelompokan provinsi. Untuk menguji sensitivitas, dilakukan beberapa skenario pembobotan yang merujuk pada salvaty,dkk (2004). Untuk menguji validitasnya, dilakukan pengujian korelasi antara IHM dengan IPM. Analisis inferensia dilakukan dengan pengujian korelasi antara IHM dengan Inkesra untuk melihat hubungan diantara keduanya serta hubungan antara masing-masing aspek. Pengujian korelasi antara masing-masing aspek dalam IHM dilakukan untuk membuktikan teori Tri Hita Karana yang menjelaskan bahwa terdapat keterkaitan antara hubungan manusia dengan 
Tuhan, alam dan manusia lainnya. Pengujian korelasi dilakukan dengan Uji Pearson dengan syarat data berdistribusi normal.

\section{HASIL DAN PEMBAHASAN}

\section{INDIKATOR PENYUSUN IHM}

Tabel 1. Ringkasan Proses Pembentukan Indeks Hubungan Manusia.

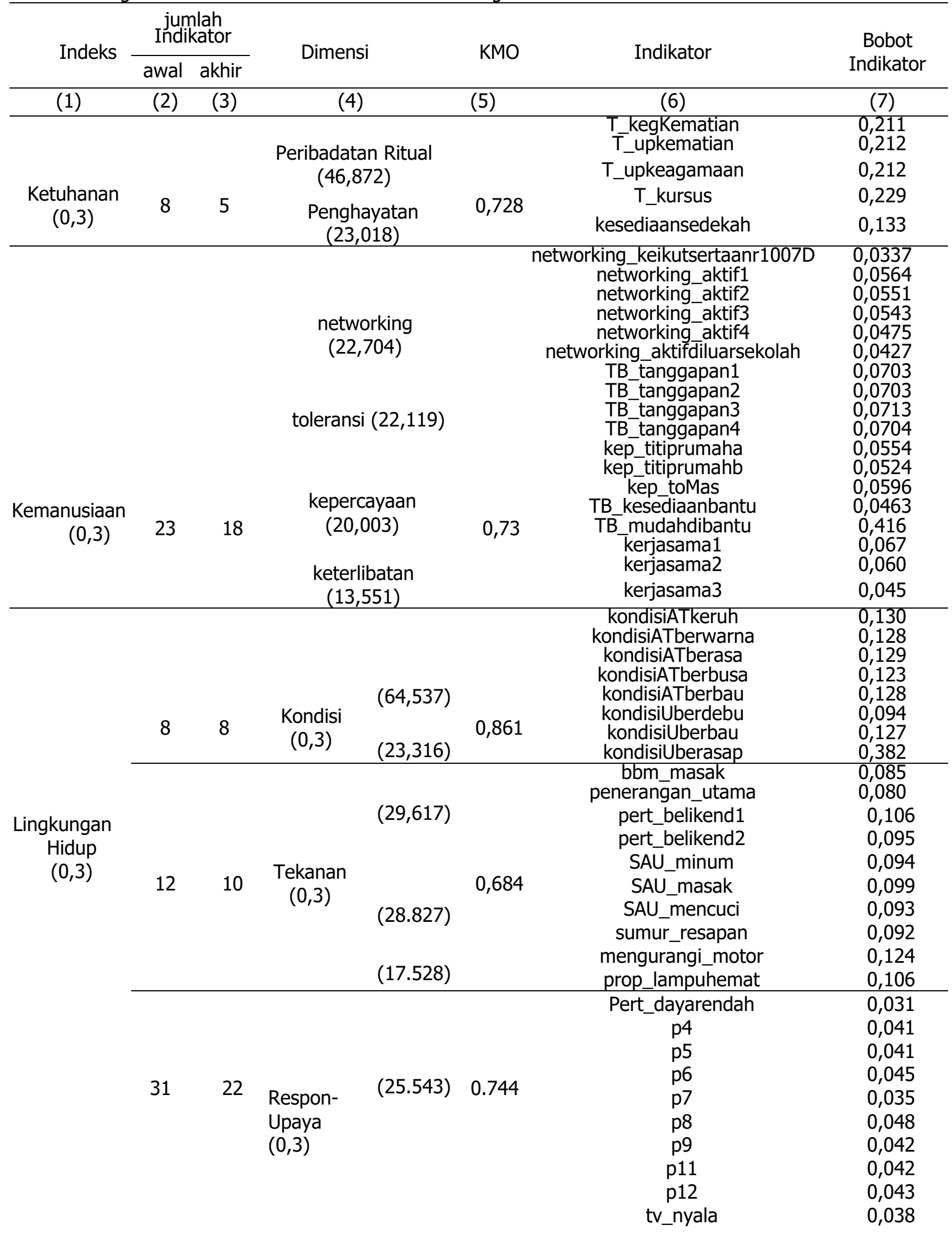


(24.581)

(14.939)

(12.884)

$\begin{array}{cc}\text { ac_nyala } & 0,047 \\ \text { kipas_nyala } & 0,046 \\ \text { komp_nyala } & 0,048 \\ \text { perlakuan_sampah } & 0,046 \\ \text { tas_belanja_sendiri } & 0,044 \\ \text { p1 } & 0,054 \\ \text { p2 } & 0,068 \\ \text { p10 } & 0,069 \\ \text { pilah_sampah } & 0,046 \\ \text { nutup_panci } & 0,039 \\ \text { radio_nyala } & 0,029 \\ \text { pompaair_nyala } & 0,048\end{array}$

0,047

0,048

0,046

0,044

0,068

0,069

0,039

0,029

indikator yang tereduksi. Reduksi dilakukan satu persatu pada masing-masing proses ekstraksi dengan menghilangkan indikator yang memiliki nilai MSA $<0,50$. Indeks Ketuhanan membentuk 2 faktor dengan kumulatif presentase varians sebesar 69,89. Pada penyusunan Indeks Kemanusiaan, didapatkan 18 indikator signifikan dengan nilai KMO sebesar 0,73 $(>0,50)$ dan terbentuk 4 faktor dengan kumulatif presentase varians sebesar 78,376. Pada penyusunan Indeks Lingkungan Hidup, didapatkan 22 indikator signifikan dengan nilai KMO dan kumulatif presentase varians (berturutturut 87,853\%; 75,972\%; 77,947\%) pada masing-masing dimensi telah memenuhi syarat. Selanjutnya dilakukan perhitungan nilai kontribusi indikator/pembobotan indikator. Selanjutnya, dilakukan agregasi untuk membentuk indeks komposit dengan bobot equal. Setelah agregasi dilakukan, didapatkan hasil perhitungan Indeks Hubungan Manusia 2018.

\section{HASIL PENGUJIAN VALIDITAS}

Tabel 2. Hasil Uji Korelasi IHM.

\begin{tabular}{llll}
\hline & Indeks lain & \multicolumn{1}{c}{ IHM } \\
$(3)$
\end{tabular}

Sumber : Data diolah

Keterangan : **tingkat signifikansi $1 \%$, *tingkat signifikansi $5 \%$

Dari tabel di atas dapat diketahui bahwa nilai signifikansi $p$-value sebesar $0.01(<0.05)$ maka tolak hipotesis nol (H1). Kesimpulannya terdapat cukup bukti untuk membuktikan adanya hubungan antara IHM dan IPM. Besarnya korelasi adalah 0.436. Begitu pula dengan Inkesra, nilai signifikansi $p$-value sebesar $0.001(<0.05)$ maka tolak hipotesis nol $(\mathrm{H} 1)$. Kesimpulannya terdapat cukup bukti untuk membuktikan adanya hubungan antara IHM dan Inkesra. Besarnya korelasi adalah 0.554.

\section{HASIL PENGUJIAN ROBUSTNESS}

Pengujian Robustness dilakukan untuk melihat kekuatan dan kestabilan indeks dalam mengukur suatu kondisi. Dilakukan pengujian terhadap tiga jenis metode poembobotan, yaitu metode pembobotan dengan loading factor, metode pembobotan skor faktor dan metode pembobotan equal. Metode terbaikadalah metode dengan nilai perbandingan terkecil.

Tabel 3. Hasil Pengujian Robustness.

\begin{tabular}{cccccc}
\hline $\begin{array}{c}\text { Metode } \\
(1)\end{array}$ & $\begin{array}{c}\text { Ketuhanan } \\
(2)\end{array}$ & $\begin{array}{c}\text { Kemanusiaan } \\
(3)\end{array}$ & $\begin{array}{c}\text { Kondisi } \\
(4)\end{array}$ & $\begin{array}{c}\text { Tekanan } \\
(5)\end{array}$ & $\begin{array}{c}\text { Respon-Upaya } \\
(6)\end{array}$ \\
\hline $\begin{array}{c}\text { Loading } \\
\text { factor }\end{array}$ & 0,941 & $\mathbf{1 , 3 2 4}$ & $\mathbf{0 , 6 4 7}$ & $\mathbf{2 , 0 8 8}$ & $\mathbf{5 , 5 0 0}$ \\
\hline
\end{tabular}




\begin{tabular}{cccccc} 
skor faktor & 0,765 & 1,745 & 2,098 & 2,686 & 5,863 \\
equal & $\mathbf{0 , 5 8 8}$ & 1,882 & 1,676 & 2,294 & 6,971 \\
\hline
\end{tabular}

\section{ANALISIS INDEKS HUBUNGAN MANUSIA}

Indeks Hubungan Manusia merupakan gabungan dari ketiga indeks tunggal yaitu indeks ketuhanan, indeks kemanusiaan dan indeks lingkungan hidup Indeks ini menunjukkan besarnya kondisi hubungan manusia dengan Tuhan, manusia lain dan alam sekitarnya di setiap provinsi di Indonesia. Indeks ini dapat mengukur posisi suatu provinsi terhadap posisi provinsi lain. Hasil agregasi menunjukkan nilai IHM setiap provinsi. Secara keseluruhan, nilai IHM berada pada interval 35-70 dengan jangkauan nilai antara provinsi tertinggi dan terendah yang cukup jauh.

Provinsi dengan nilai IHM tertinggi yaitu DIY, yang berarti masyarakat Provinsi DIY memiliki keseimbangan hubungan yang baik antara hubungan manusia dengan tuhan, manusia lain dan alam. Hal ini dapat dimaklumi karena DIY mencantumkan urusan budaya dalam urusan pemerintahannya dan kebudayaan memberi kontribusi besar terhadap peningkatan kesejahteraan rakyat DIY (Kuncahyo, 2017). Sedangkan, Provinsi Papua menjadi provinsi dengan nilai hubungan manusia yang terendah dari seluruh provinsi di Indonesia dengan jarak yang cukup jauh dan tertinggal daripada provinsi lain.

\section{PENGELOMPOKAN PROVINSI}

Untuk mempermudah melihat sebarannya, dilakukan pengelompokan provinsi menggunakan natural breaks pada aplikasi geoda. Hasilnya sebagai berikut.
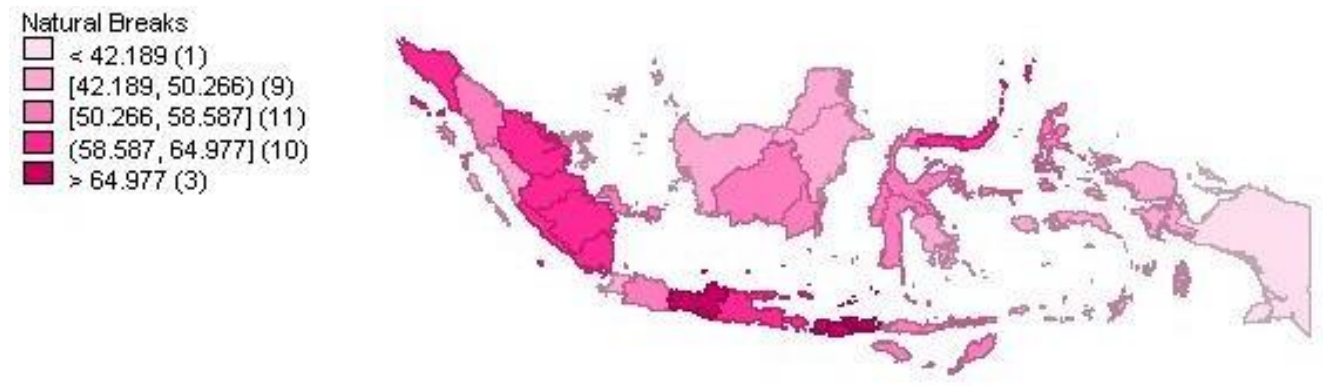

Gambar 1. Peta Tematik IHM 2018.

Provinsi-provinsi yang berkategori tinggi dan sangat tinggi berjumlah 13 provinsi dan mengelompok di pulau Sumatera, Jawa dan Sulawesi serta Provinsi NTB dan Gorontalo. Untuk kategori sedang, terdapat 11 provinsi yang didominasi oleh wilayah tengah dan timur Indonesia seperti Kepulauan Maluku, provinsi- provinsi di Pulau Sulawesi serta beberapa provinsi di bagian barat Indonesia. Sedangkan untuk kategori rendah terdapat pada sebagian besar Pulau Kalimantan dan untuk kategori sangat rendah, terdapat satu provinsi yaitu Provinsi Papua.

Tabel 4. Pengelompokan provinsi berdasarkan IHM 2018

Pengelompokan provinsi menurut IHM 2018

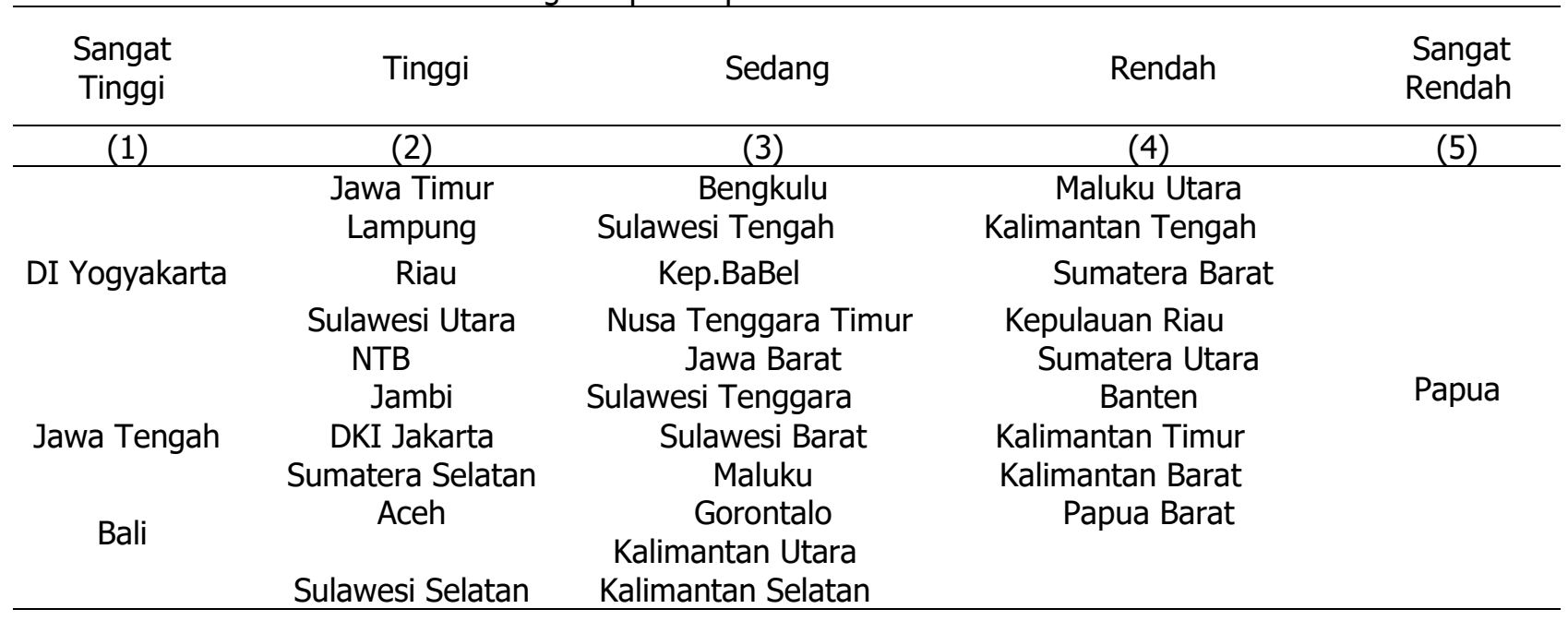


Kecenderungan atau mengumpulnya nilai IHM dominasi ini dapat dikaitkan dengan IPM pada masing-masing wilayah. Secara umum, sebaran IHM selaras dengan IPM. Wilayah timur Indonesia memiliki IPM yang cenderung rendah sedangkan wilayah barat Indonesia memiliki IPM yang tinggi. Katerogi sangat rendah dan rendah pada IHM dimiliki oleh provinsi dengan kategori rendah pula pada IPM. Begitupula pada kategori sedang, tinggi dan sangat tinggi. Namun terdapat perbedaan pada dua provinsi. Apabila dibandingkan dengan sebaran Inkesra, IHM memiliki sebaran yang cukup sama. Namun, terjadi perbedaan pada Provinsi Kalimantan Utara dan Timur. Kedua provinsi ini memiliki nilai inkesra yang tinggi, tetepi IHM rendah.

Tabel 5. Resume nilai Indeks IHM dan Indeks Tunggal penyusun IHM pada 3 provinsi tertinggi dan terendah se-Indonesia.

\begin{tabular}{|c|c|c|c|c|c|c|}
\hline \multirow{2}{*}{$\begin{array}{c}\text { Indeks } \\
\text { (1) }\end{array}$} & \multicolumn{5}{|c|}{ Urutan Provinsi } & \multirow[b]{2}{*}{$\begin{array}{l}34 \\
(7) \\
\end{array}$} \\
\hline & $\begin{array}{c}1 \\
(2)\end{array}$ & $\begin{array}{c}2 \\
(3)\end{array}$ & $\begin{array}{r}3 \\
(4)\end{array}$ & $\begin{array}{l}32 \\
\text { (5) }\end{array}$ & $\begin{array}{l}33 \\
(6)\end{array}$ & \\
\hline IHM & $\begin{array}{c}\text { DI } \\
\text { Yogyakarta } \\
70.98 \\
\end{array}$ & $\begin{array}{c}\text { Jawa } \\
\text { Tengah } \\
68.59\end{array}$ & $\begin{array}{c}\text { Bali } \\
65.47\end{array}$ & $\begin{array}{r}\text { Kalimantan } \\
\text { Barat } \\
50.75 \\
\end{array}$ & $\begin{array}{c}\text { Papua Barat } \\
48.10\end{array}$ & $\begin{array}{l}\text { Papua } \\
34.55 \\
\end{array}$ \\
\hline $\begin{array}{l}\text { Indeks } \\
\text { Ketuhanan }\end{array}$ & Aceh & $\begin{array}{l}\text { Nusa } \\
\text { Tenggara } \\
\text { Barat }\end{array}$ & Jambi & $\begin{array}{l}\text { Sulawesi } \\
\text { Tenggara }\end{array}$ & Papua Barat & Papua \\
\hline & 83.77 & 77.40 & 69.95 & 31.80 & 25.21 & 9.68 \\
\hline $\begin{array}{c}\text { Indeks } \\
\text { Kemanusiaan }\end{array}$ & $\begin{array}{c}\text { DI } \\
\text { Yogyakarta } \\
81.055\end{array}$ & $\begin{array}{l}\text { Jawa } \\
\text { Tengah } \\
70.187\end{array}$ & $\begin{array}{c}\text { Bali } \\
68.207\end{array}$ & $\begin{array}{r}\text { Sumatera } \\
\text { Barat } \\
37.455\end{array}$ & $\begin{array}{l}\text { Banten } \\
36.655\end{array}$ & $\begin{array}{l}\text { Papua } \\
33.410\end{array}$ \\
\hline $\begin{array}{l}\text { Indeks } \\
\text { Lingkungan } \\
\text { Hidup }\end{array}$ & $\begin{array}{c}\text { DI } \\
\text { Yogyakarta } \\
73.86\end{array}$ & $\begin{array}{c}\text { Lampung } \\
72.23\end{array}$ & $\begin{array}{l}\text { Jawa } \\
\text { Tengah } \\
70.51\end{array}$ & $\begin{array}{c}\text { Kalimantan } \\
\text { Timur } \\
45.41\end{array}$ & $\begin{array}{l}\text { Kepulauan } \\
\text { Riau } \\
41.33\end{array}$ & $\begin{array}{l}\text { Papua } \\
37.67\end{array}$ \\
\hline
\end{tabular}

\section{PERBANDINGAN ASPEK DOMINAN}

Kecenderungan capaian yang beragam tersebut menunjukkan bahwa pencapaian nilai IHM yang tinggi dihasilkan dari tingginya pula nilai indeks penyusunnya. Apabila terdapat provinsi dengan nilai salah satu indeks yang tinggi akan tetapi memiliki nilai yang rendah pada indeks lain, maka tidak akan mencapai nilai yang tinggi untuk IHM. Hal ini menunjukkan perlunya keselarasan dan keseimbangan hubungan antara ketiga aspek dalam membangun harmonisasi yang baik. Untuk lebih jelasnya, dapat dilihat pada spider chart berikut

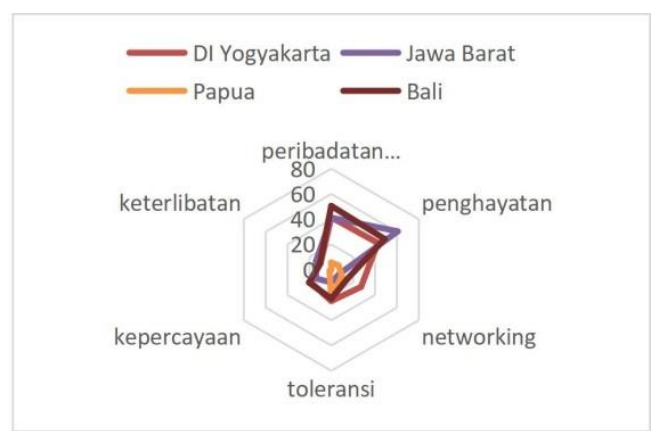

Gambar 2. Perbandingan aspek dominan indeks ketuhanan dan kemanusiaan.

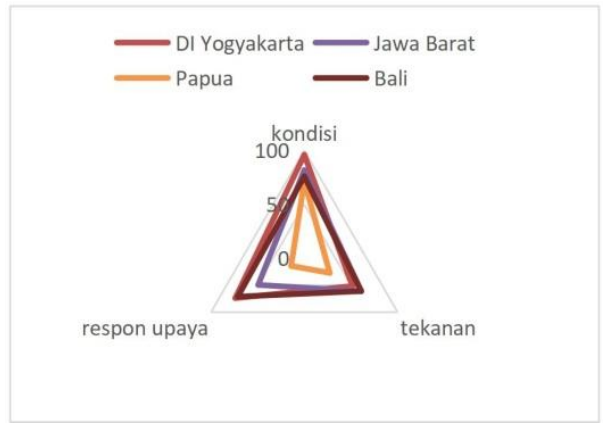

Gambar 3. Perbandingan aspek dominan indeks lingkungan hidup.

Penyajian spider chart dipisah menjadi dua karena menyesuaikan skala pembentukan dimensi tersebut. Gambar 10 dan 11 menunjukkan ketercapaian dan gambaran aspek dominan pada Provinsi DIY (provinsi IHM tertinggi), Provinsi Bali (provinsi ketiga IHM tertinggi), Provinsi Jawa Barat (provinsi urutan ke 18 IHM) dan Provinsi Papua (provinsi dengan nilai IHM terendah) di Indonesia. Provinsi DIY merupakan provinsi dengan IHM tertinggi, apabila dilihat dari dimensi penyusunnya secara umum nilainya tinggi pada tiap dimensi tetapi terdapat dimensi yang kurang tinggi apabila dibandingkan dengan provinsi lain, yaitu dimensi keterlibatan. Hal yang sama dapat dilihat pula pada Provinsi Bali, Provinsi Papua dan Provinsi 
Jawa Barat apabila dibandingkan dengan Provinsi DIY memiliki dimensi yang lebih unggul. Perbedaan ini menunjukkan bahwa setiap provinsi memiliki karakteristiknya masing-masing dan dapat menjadi keunggulan bagi provinsi tersebut untuk mengembangkan dimensi yang sudah baik. Selain itu, dimensi yang rendah dapat dilihat lebih jauh dipertimbangkan. Hubungan dengan indikator lain dan hubungan antar ketiga aspek

Tabel 6. Hasil Uji Korelasi 3 Aspek.

\begin{tabular}{|c|c|c|c|c|}
\hline & & Indeks & Indeks & Indeks LH \\
\hline (1) & (2) & (4) & (5) & (6) \\
\hline Indeks Ketuhanan & $\begin{array}{l}\text { Pearson } \\
\text { Correlation }\end{array}$ & 1 & 0,372* & $0,462 * *$ \\
\hline & $\begin{array}{l}\text { Sig. } \\
\text { tailed) }\end{array}$ & & 0,03 & 0,006 \\
\hline Indeks Kemanusiaan & $\begin{array}{l}\text { Pearson } \\
\text { Correlation }\end{array}$ & $0,372 *$ & 1 & $0,366 *$ \\
\hline & $\begin{array}{l}\text { Sig. } \\
\text { tailed) }\end{array}$ & 0,03 & & 0,033 \\
\hline Indeks LH & $\begin{array}{l}\text { Pearson } \\
\text { Correlation }\end{array}$ & $0,462 * *$ & 0,366* & 1 \\
\hline & $\begin{array}{l}\text { Sig. (2- } \\
\text { tailed) }\end{array}$ & 0,006 & 0,033 & \\
\hline
\end{tabular}

Sumber : Data diolah

Keterangan : **tingkat signifikansi $1 \%$, *tingkat signifikansi $5 \%$

Dari tabel di atas dapat diketahui bahwa apabila dilakukan uji indeks tunggal, seluruh indeks memiliki $p$-value kurang dari 0,05 yang artinya terdapat cukup bukti untuk menunjukkan adanya hubungan diantara kedua indeks. Pengujian hubungan antara Indeks Ketuhanan dengan Indeks Lingkungan Hidup menunjukkan hasil pengujian signifikan dengan korelasi sebesar 0.462 sedangkan dengan Indeks Kemanusiaan berkorelasi pula sebesar 0,372. Angka ini menunjukkan terdapat hubungan diantara indeks yang diuji, meskipun tidak terlalu kuat. Selain itu, hasil pengujian korelasi antara Indeks Kemanusiaan dan Indeks Lingkungan Hidup menunjukkan hasil yang signfikan positif, dengan korelasi sebesar 0,366. Hasil ini membuktikan hipotesis penelitian yang menyatakan bahwa aspek hubungan manusia dengan tuhan, dengan manusia lainnya dan dengan alam sekitar memiliki keterkaitan.

\section{KESIMPULAN}

Berdasarkan hasil analisis dan pembahasan, kesimpulan yang dapat diambil dari penelitian ini adalah Indeks Hubungan Manusia dapat menjadi barometer/ alternatif indikator untuk mengukur kualitas hubungan manusia dengan Tuhan, manusia, dan alam, dalam menunjang ketercapaian keharmonisan di setiap aspek. Indeks Hubungan Manusia tertinggi terdapat pada Provinsi Yogyakarta, Jawa Tengah dan Bali yang artinya masyarakat pada ketiga provinsi tersebut memiliki hubungan yang baik dengan Tuhan, manusia dan alam. Terdapat 64 indikator penyusun Indeks Hubungan Manusia yang terbagi dalam ketiga indeks tunggal dengan nilai KMO dan presentase kumulatif varians yang memenuhi. Ketiga indeks tunggal tersebut tersusun atas beberapa dimensi dengan rincian sebagai berikut : a) Indeks Ketuhanan tersusun atas dimensi Peribadatan Ritual dan Pengahayatan, b) Indeks Dimensi Kemanusiaan tersusun atas dimensi networking, kepercayaan, toleransi dan timbal balik, c)Indeks Lingkungan Hidup tersusun atas dimensi kondisi, tekanan dan respon upaya. Terdapat kondisi aspek dominan yang variatif antar provinsi. Pengujian korelasi antar masing-masing indeks tunggal menunjukkan terdapat korelasi antara setiap aspek hubungan manusia pada tahun 2018 di Indonesia.

\section{UCAPAN TERIMA KASIH}

Penelitian ini merupakan bentuk rasa syukur penulis kepada Tuhan. Ucapan terima kasih diberikan kepada dosen pembimbing yang telah memberikan kepercayaan kepada penulis untuk 
merealisasikan ide topik ini, dosen penguji, orangtua dan teman-teman. Semoga dapat menjadi kebermanfaatan yang luas untuk STIS, BPS, Indonesia dan semua pembaca.

\section{DAFTAR PUSTAKA}

Abdullah, I. (2002). Tantangan Pembangunan Ekonomi dan Transformasi Sosial: Suatu Pendekatan Budaya. Jurnal Humaniora, 14(3), 260-270.

BPS. (2017). Indeks Kebahagiaan 2017. Agustus. Jakarta: Badan Pusat Statistik.

BPS. (2018). Indeks Pembangunan Kebudayaan 2018. Jakarta: Badan Pusat Statistik, Kementrian Pendidikan dan Kebudayaan, dan BPPN

BPS. (2018). Laporan Indeks Perilaku Ketidakpedulian Lingkungan Hidup Indonesia 2018. Jakarta: BPS-RI.

BPS. (2019).Sistem Terintegrasi Neraca Lingkungan dan Ekonomi Indonesia 2014-2018. Jakarta: BPS.

Fauzi, A., \& Oxtavianus, A. (2014). Pengukuran pembangunan berkelanjutan di Indonesia. Mimbar: Jurnal Sosial dan Pembangunan, 30(1), 42-52.

Indonesia, P. R., \& Nusantara, W. (1997). Undang Undang No. 23 Tahun 1997 Tentang: Pengelolaan Lingkungan Hidup. Sekretariat Negara, Jakarta.

Indonesia, T. P. K. B. B. (2008). Kamus besar bahasa Indonesia. Jakarta: Balai Pustaka. Jakarta, B. P.

L. H. D. (2015). Laporan status lingkungan hidup daerah provinsi Daerah Khusus Ibukota Jakarta Tahun 2015. Pemerintah Provinsi Daerah Khusus Ibukota Jakarta.

Joint Research Centre-European Commission. (2008). Handbook on constructing composite indicators: methodology and user guide. OECD publishing.

Karyanto, P. (2010). Kerangka Konseptual (Conceptual Framework) Untuk Analisis Pertanian Upland Berkelanjutan. In Prosiding Seminar Biologi (Vol. 7, No. 1).

Kota, S. T. U. M. P., Manusia, B., \& Nugroho, I. (1997). SOCIAL CAPITAL DAN PERKEMBANGAN KOTA1.

Marfai, M. A., Rahayu, E., \& Triyanti, A. (2018). Peran Kearifan Lokal Dan Modal Sosial Dalam Pengurangan Risiko Bencana Dan Pembangunan Pesisir:(Integrasi Kajian Lingkungan, Kebencanaan, dan Sosial Budaya). UGM PRESS.

Meadows, D. H., Meadows, D. L., Randers, J., \& Behrens, W. W. (1972). The limits to growth. New York, 102, 27.

Nasution, A., Rustiadi, E., Juanda, B., \& Hadi, S. (2014). Dampak modal sosial terhadap kesejahteraan Rumah Tangga Perdesaan di Indonesia. Mimbar: Jurnal Sosial dan Pembangunan, 30(2), 137-148.

Pembukaan UUD. (1945). Dan Batang Tubuh

POLITEKNIK STATISTIKA STIS. (2019). 08 Buku Seri Laporan Hasil PKL 2018/2019 SUBAK DAN IMPLEMENTASI TRI HITA KARANA. Agustus. Jakarta: Politeknik Statistika STIS.

Rahadian, A. H. (2016). Strategi pembangunan berkelanjutan. In Prosiding Seminar STIAMI (Vol. 3, No. 1, pp. 46-56).

Sari, D. A. (2016). Analisis Faktor-faktor yang mempengaruhi kesejahteraan masyarakat di Kota Bandarlampung.[SKRIPSI]

Salvati, L., \& Carlucci, M. (2014). A composite index of sustainable development at the local scale: Italy as a case study. Ecological Indicators, 43, 162-171.

Sekaran, U., \& Bougie, R. (2016). Research methods for business: A skill building approach. John Wiley \& Sons.

Sharma, S., \& Sharma, S. (1996). Applied multivariate techniques.

Sitepu, A. (2017). Organisasi Sosial Lokal: Profil, Peran dan Rekomendasi untuk Pembangunan Kesejahteraan Sosial. Sosio Konsepsia, 11(2), 11-23.

Supranto, J. (2004). Analisis Multivariat Arti dan Interpretasi. Rineka Cipta, Jakarta. Wiana, I

Ketut. (2007). Tri Hita Karana menurut Konsep Hindu. Surabaya: Paramita. 